\title{
The influence of information sharing, supplier trust and supplier synergy on supplier performance: The case of small and medium enterprises
}

\begin{abstract}
Authors:
David Pooe ${ }^{1}$

Chengedzai Mafini ${ }^{2}$

Vandrys W. Loury-Okoumba²

Affiliations:

${ }^{1}$ Department of Business Management, University of Johannesburg, South Africa

${ }^{2}$ Department of Logistics, Vaal University of Technology, South Africa

\section{Correspondence to:}

David Pooe

Email:

dpooe@uj.ac.za

\section{Postal address:}

Private Bag X09,

Johannesburg 2013,

South Africa

\section{Dates:}

Received: 17 Apr. 2015

Accepted: 05 Aug. 2015

Published: 06 Oct. 2015

How to cite this article: Pooe, D., Mafini, C. \& LouryOkoumba, V.W., 2015, 'The influence of information sharing, supplier trust and supplier synergy on supplier performance: The case of small and medium enterprises', Journal of Transport and Supply Chain Management 9(1), Art. \#187, 11 pages. http://dx.doi. org/10.4102/jtscm.v9i1.187

\section{Copyright:}

(C) 2015. The Authors. Licensee: AOSIS OpenJournals. This work is licensed under the Creative Commons Attribution License.
\end{abstract}

Background: The assessment of supplier performance is an important activity for small to medium enterprises (SMEs) as they adopt and implement plans and policies aimed at enhancing their performance in order to achieve sustainable competitive advantages.

Objectives: The purpose of this study was to examine the influence of information sharing, supplier trust and supplier synergy on supplier performance in SMEs.

Method: A quantitative research design was adopted in which a survey questionnaire was administered to a sample of 309 owners and managers of SMEs based in southern Gauteng, South Africa. A confirmatory factor analysis was undertaken to assess the properties of the measurement scale. Hypotheses were tested using the path modelling technique.

Results: Information sharing exerted a moderate positive and significant influence on supplier trust and a weak but sigificant influence on supplier synergy. Supplier synergy had a strong positive and significant influence on supplier performance. However, the influence of supplier trust on supplier performance was weak and insignificant.

Conclusion: The study provides a useful framework for analysing the interplay between information sharing, supplier trust, supplier synergy and supplier performance in SMEs.

\section{Introduction}

As businesses look for ways to excel in today's highly competitive world, they come to appreciate the need to look beyond their immediate environments and to consider their role in the supply chains within which they operate. The more buying firms improve their own efficiency, the more they recognise the need to pay attention to the efficiency or otherwise of their suppliers and their suppliers' suppliers. Not surprisingly, supplier performance and the factors contributing towards it have attracted the attention of managers, practitioners and researchers alike. To this end, the factors influencing supplier performance have been examined in a number of previous studies. For example, Prahinski and Benton (2004:39) considered the relationship between communication strategies and supplier performance, whilst Wu, Choi and Rungtusanatham (2010:115) investigated the implications of supplier performance in the supplier-supplier relationships in buyer-suppliersupplier triads. Aksoy and Ozturk (2011:6351) focused on the relationship between supplier selection and performance whilst Mols, Hansen and Villadsen (2012:874) investigated the effect of internal production on supplier performance. A common thread underlying the results of these studies is the enduring influence of supplier performance on business performance.

Enhancing supplier performance calls for the strengthening of buyer-supplier relationships (Talluri \& Sarkis 2002:4257). Supplier performance may be perceived as how well a supplier is able to provide the required products to the buyer as evidenced through operational outcomes such as quality, delivery, responsiveness, cost and technical support (Wu et al. 2010:116). Ho et al. (2012:7108) add that other factors that may be associated with supplier performance include supplier trust, synergy and information sharing. As observed by some scholars (Kim 2000:388; Nielsen \& Nielsen 2009:1031) supplier trust is crucial in establishing long-term buyer-supplier relationships. Therefore, the relevance and importance of supplier trust as a possible factor in enhancing supplier performance is worthy of investigation.

Supplier synergy is an important factor in that it enables supply chain partners to collaborate with each other with a view to achieving common goals, by for example sharing or acquiring resources and expertise that other parties may lack (Osarenkhoe 2010:201), resulting in improved efficiency and enhanced overall supplier performance (Krause, Handfield \& Tyler 2007:528; Wong, Lai \& Ngai 2009:47). Moreover, supplier trust and supplier synergy also depend to a large extent on 
information sharing (Hartono et al. 2010:399; Nicolaou, Ibrahim \& Van Heck 2013:986). Relevant information shared between supply chain members requires suppliers to trust and rely on their partner's capability to operate. Thus, there is seemingly an interplay between information sharing, supplier trust and supplier synergy and all these factors seem to be critical for improving supplier performance.

The aim of this study is to determine the influence of information sharing, supplier trust and supplier synergy on supplier performance amongst small to medium enterprises (SMEs). The study was conducted within the population of SMEs in southern Gauteng, South Africa. To achieve this aim, four objectives were set: (1) to determine the influence of information sharing on supplier trust, (2) to determine the influence of information sharing on supplier synergy, (3) to determine the influence of supplier trust on supplier performance and (4) to determine the influence of supplier synergy on supplier performance. For the purposes of this study, SMEs are defined as firms in which the owners are directly involved in management and which employ a maximum of 500 employees (Mahadea \& Pillay 2008:435). There have been few studies conducted on supplier performance from the South African perspective, apart from some which focused on buyer-supplier collaboration (e.g. Parker 2007:207; Pooe \& Mathu 2011:316) and the impact on information sharing and trust in enabling supply chains (e.g. Piderit, Flowerday \& Von Solms 2011:473). The majority of studies on supplier performance were conducted within the European and North American contexts, with few focusing on the SME sector - a sector that is characteristically different in South Africa (Adams, Khoja \& Kauffman 2012:20; Perrini 2006:305). This is notable, considering the role and contribution of SMEs in economies (Cant \& Wild 2013:710). In addition, the view that there is scant evidence of literature on supplier performance within the South African SME environment will enable this study to address these existent research gaps. The remainder of the article is organised as follows. The next section reviews literature in the areas of information sharing, supplier trust, supplier synergy and supplier performance. It is followed by sections on research methodology and one that reports on the results of the study. Finally, the article concludes with the implications of the study and future research directions.

\section{Literature review \\ Theoretical framework}

This study is premised on the collaboration theory, which postulates that collaboration is key to problem solving in every sector of the economy (Gray 1985:911). Collaboration relates to a joint decision-making strategy designed to collectively share resources and with the ultimate objective of solving problems and challenges that one cannot otherwise resolve (Selin \& Chavez 1995:190). Effective collaboration is a source of competitive advantage that aims to improve customer service, profit generation, asset utilisation and cost reduction (Pooe \& Mathu 2011:320). Characterising the collaboration theory are five elements, namely (1) the independence of stakeholders, (2) solutions to problems and other challenges are found through mutual understanding cooperation, (3) parties must contribute to decision-making, (4) parties must take responsibility on the development of the strategy and (5) parties must understand the salient point of the strategy plan as it is there to provide a foundation from which they can manage and deal with the uncertainty of the environment in which they are operating (Gray 1989:227). This theory was deemed appropriate for this study since it is about the effective and efficient interaction of parties through the mutual sharing of input resources. Furthermore, the article contends that collaboration underpins information sharing, supplier trust and supplier synergy.

\section{Small and medium enterprises}

There is now hardly any dispute about the role and contribution of SMEs in economies. The SME sector has been described as an essential factor in sustaining the economic growth and development of most economies due to their abilities to adjust to environmental changes and technological orientation (Adams et al. 2012:25). According to Abor and Quartey (2010:220), the SME sector has massively contributed to growth and development of the South African economy, especially in the area of employment creation, which is crucial in fostering and improving socio-economic development, alleviating poverty and reducing crime. Not surprisingly, the performance of SMEs has generated great attention from scholars and other decision-makers (Alpkan, Yilmaz \& Kaya 2007:152; Sandada, Pooe \& Dhurup 2014:662). In his study on SME performance, Sidik (2012:376) conceptualised SME performance in terms of its ability to increase or improve its overall outcomes in terms of cash flow, profitability, customer satisfaction, sales growth and employee growth. Since there is usually little separation between ownership and control of operational activities in SMEs, Ahmad, Halim and Zainal (2010:67) posit that the success of SMEs is related to the abilities of their owners to make the best use of their managerial skills, experience and expertise. Due to their socio-economic role and importance, it was found critical that the influence of information sharing, supplier trust and supplier synergy on supplier performance be investigated from the perspective of SMEs.

\section{Information sharing}

Information is vital for the effective functioning of any business. It has been described as the lifeblood of organisations. Information sharing refers to the extent to which a firm openly communicates important and sensitive information to its partners (Shou et al. 2012:2). The notion of information sharing has attracted significant attention from a number of scholars who have stressed its role and influence in the supply chain environment (e.g. Jraisat, Gotsi \& Bourlakis 2013:323; Kembro \& Naslund 2014:179; Leung, Choy \& Kwong 2010:64). Information sharing has also been regarded as an effective predictor factor of a supply chain's effectiveness (Zhang \& 
Chen 2013:181). In that regard, a study by Hsu et al. (2008:297) found that information sharing contributes largely to improved relationships between suppliers by facilitating efficient coordination and responsiveness as well as integration of partners' information systems. Furthermore, effective sharing of information between supply chain members has also been determined to be a crucial antecedent aspect in mitigating the negative impact of the bullwhip effect (Kelepouris, Miliotis \& Pramatari 2008:3657). Chinomona and Pooe (2013:8) found that timely and accurate sharing of strategic information can foster the reduction of unwarranted wastages and costs in a supply chain, thus leading to increased SME profitability. Since information sharing is considered so important for effective supply chains, it is a factor worthy of investigation in the case of supplier performance, especially in the context of SMEs.

\section{Supplier trust}

Supplier trust is another key variable in this study. Supplier trust has been defined by Cavusgil, Deligonul and Zhang (2004:7) as the confidence that trading partners have about each other's reliability and integrity. Trust has been defined to be an important contributor and facilitator to any transaction that calls for a mutual involvement and collaboration of diverse parties (Cheung et al. 2011:184). Supplier trust has also received attention from a number of scholars who have extensively investigated its impact and relevance in buyer-supplier relationship (Bonte 2008:855; Gao, Sirgy \& Bird 2005:397; Kwon \& Suh 2005:26; Wasti \& Wasti 2008:118). Trust between suppliers and the buying firm has been viewed to be an important predictor factor impacting on suppliers' ability to integrate their supply chain activities (Yeung et al. 2009:66). According to Panayides and Lun (2009:35), supplier trust plays a vital role in enabling and enhancing a firms' innovativeness and consequently its supply chain performance outcomes. In light of the fact that it is so vital for SMEs to be integrated in supply chains, it is imperative that supplier trust be well understood.

\section{Supplier synergy}

Supplier synergy is yet another important aspect deserving of a clearer understanding. Supplier synergy can be defined as the coordination and complementarity of similar activities performed by two or more firms, groups or individuals in a business relationship to produce superior mutual outcomes (Osarenkhoe 2010:201). According to Hoegl and Wagner (2005:530), supplier synergy has a positive effect on the organisation's ability to provide a quality product to their customers. This reflects the importance that coordinated work between suppliers' parties has on the competitiveness of a firm's supply chain. Wu et al. (2010:117) believe that supplier synergy allows firms to eliminate or lessen the recurrent technical and quality problems in production. Besides, effective synergistic collaboration also leads to the sharing of strategic and key explicit and tactic knowledge. In their study, Yeung et al. (2013:546) postulate that sound synergy enables businesses to obtain great benefits, such as improved quality of products and flexibility of operations. Thus, supplier synergy reduces unnecessary duplications responsible for possible inefficiencies within the supply chain. Therefore, supplier synergy becomes ever so critical for SMEs characterised by flexibility of operations and whose quality of products is constantly under scrutiny.

\section{Supplier performance}

Perhaps the most important yardstick to determine the success of suppliers is their performance. Wu et al. (2010:115) define supplier performance as how well a supplier supplies the required products to the buyer as reflected through operational outcomes such as quality, delivery, responsiveness, cost and technical support. Huang, Yen and Liu (2014:64) posit that a firm's effort to adequately integrate its supply chain activities has a massive impact on their supplier performance. In addition, supplier performance has been described as a major predictor of reseller satisfaction (Yilmaz, Sezen \& Kabadayi 2004:854). Thus, well-performing suppliers represent a key factor that businesses should strive to develop and maintain in their long-term sustainability and profit's aspiration (SanchezRodriguez, Hemsworth \& Martinez-Lorente 2005:289). Krause et al. (2007:528) further suggest that a supplier performing at optimal level is crucial in enabling the buying firm to reach its performance outcomes in terms of serving its customers more efficiently. A well-performing supplier is likely to remain in the supply chain and grow its relationship with the buying firms - something that all SMEs should aspire to.

\section{Conceptual framework and hypothesis development}

The following conceptual framework highlights the causal relationships under investigation. This framework is made of one predictor variable, namely information sharing, two mediating variables, namely supplier trust and synergies, as well as the outcome variable, which is supplier performance. This conceptualised framework is illustrated in Figure 1.

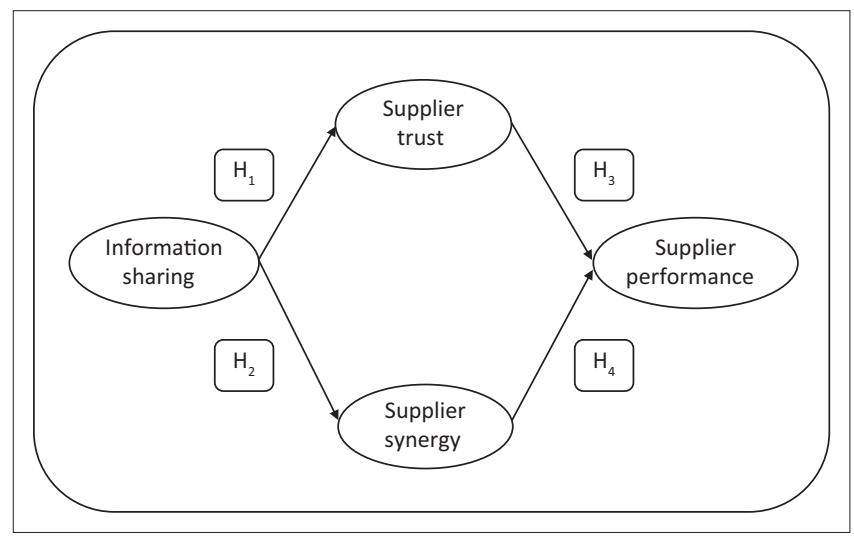

FIGURE 1: Conceptual framework 


\section{Information sharing and supplier trust}

Information sharing has always been highly regarded as an effective facilitator and a key enabler of collaboration between supply chain members (Cheng \& Wu 2005:1159), which suggests the vital role that information sharing has in contributing to the development and improvement of activities performed by firms' supplier partners. This view has been further stretched by Gosh and Fedorowicz (2008:453) who posit that sound and accurate exchange of sensitive and strategic information amongst supplier is important for the establishment of strong and long-lasting trusting relationship between the supply chain partners. Furthermore, concise sharing of information has been described as a prerequisite of strengthening buyer-supplier trust in that it enables them to collectively share the same objectives and develop mutual problem resolutions (Kwon \& Suh 2005; Nyaga, Whipple \& Lynch 2010:101). Moreover, Doney and Cannon (1997:41) assert that the ability and willingness to openly share confidential information portrays their trustworthiness to engage in a sound and collaborative type of relationship. Based on the aforementioned, the following hypothesis is postulated:

- Hypothesis 1: Information sharing between SMEs and their suppliers exerts a positive influence on supplier trust.

\section{Information sharing and supplier synergy}

The importance and impact of information sharing has been significantly investigated in a number of studies (e.g. Cheng 2011:374; Sheu, Yen \& Chae 2006:24; Zhang \& Chen 2013:178), stressing its vital role in buyer-supplier relationships. According to Barratt (2004:30), information sharing plays a pivotal role in assisting supply chain partners to collaboratively engage in mutual strategic activities and decision-making. This therefore may allow them to effectively and efficiently work together and foster the value creation of each supply chain unit in a more synergistic manner. In this regard, Prajogo and Olhager (2012:514) posit that where there is an adequate and interrupted flow of information between each unit of activity, supply chain networks can increase the suppliers' capabilities to perform synergistically. In light of the foregoing, it is hypothesised that:

- Hypothesis 2: Information sharing between SMEs and their suppliers exerts a positive influence on supplier synergy.

\section{Supplier trust and supplier performance}

Trust has been described by Zhang, Cavusgil and Roath (2003:550) as a key determinant in strong buyer-supplier relationships, as it enables supply chain partners to conduct their transactions and operations without fear of vulnerability. According to Jain et al. (2014:315), a trusting relationship between a buyer and its suppliers allows both parties to mutually share critical resources as well as strategic information freely. This therefore may enable them to obtain significant output resources that may improve the operational performance of their suppliers in terms of responsiveness, reliability and effectiveness in strategic problem resolution (Handfield \& Bechtel 2002:367; Panayides \& Lun 2009:38), which may consequently lead to the enhanced performance of the buying firm (Corsten \& Kumar 2005:80; Nielsen 2007:337). This shows the likely influence of supplier trust on supplier performance, leading to the following hypothesis:

- Hypothesis 3: Supplier trust amongst SMEs exerts a positive influence on supplier performance.

\section{Supplier synergy and supplier performance}

Suppliers engaging in synergistic collaboration have viewed it as a major strategic approach designed to enhance their core performance (Duffy \& Fearne 2004:57; Sheu et al. 2006:24). This shows the benefit that suppliers working synergistically may have in maximising their performance in achieving their goals and objectives. In this regard, Cao and Zhang (2011:168) argue that the higher the level of synergy within the supply chain, the more likely suppliers' performance will be improved. Scannell, Vickery and Droge (2000:23) and Cannon and Homburg (2001:29) posit that adequate synergy within a firm's supply chain results in better coordination and collaboration as well as a decrease in procurement costs. In view of the foregoing, it would appear that suppliers' willingness to work in a synergistic manner is crucial in enabling them to improve their performance, which subsequently may allow firms to attain and sustain their competitive advantage. Therefore, the following hypothesis is formulated:

- Hypothesis 4: Supplier synergy amongst SMEs exerts a positive influence on supplier performance.

\section{Research methodology Sample and data collection}

The sample consisted of SME companies in the Vaal Triangle (Vanderbijlpark, Vereeniging and Sasolburg). These were selected using the simple random technique, which allows for statistical inferences to be made about the target population from which the sample is drawn (Malhotra \& Birks 2007:1). Questionnaires were distributed in person by one of the researchers during the month of August 2014 with the assistance of a trained fieldworker in the distribution process to ensure a speedy and effective process. Respondents were given two weeks to complete the questionnaires. Out of the 500 questionnaires that were initially distributed, 350 were retrieved. Of these, only 309 were properly completed by respondents and therefor deemed usable for analysis, resulting in total of 41 questionnaires discarded because they were either incomplete or inaccurately completed. This yielded a response rate of approximately $61.8 \%$. The sampling frame was made up of various lists that included a register from the Gauteng Enterprise Propeller (GEP), the Vaal Triangle Business Directory as well as SME databases from relevant Sedibeng district municipality. The ethical clearance issued by the Vaal University of Technology enabled the field workers to approach prospective respondents who were 
informed that their participation in the study was voluntary and that the confidentiality of the information provided by the respondents was guaranteed. The questionnaire was completed by owners and managers of the participating SMEs.

\section{Measurement instrument and design}

Research scales were designed on the basis of previous work. Proper modifications were made in order to fit the current research context and purpose. Information sharing was measured using a six-item scale adapted from Li et al. (2006:107). Supplier trust was measured using six items adapted from Ketkar et al. (2012:791). Supplier synergy was measured using four items adapted from Ranganathan, Teo and Dhaliwal (2011:539). Last of all, supplier performance was assessed using items adapted from Prajogo et al. (2012:127). Response options were configured on five-point Likert-type scales ranging from 1 (strongly disagree) to 5 (strongly agree) to express the degree of agreement or disagreement. Likerttype scales were chosen mainly because they are considered to be appropriate in assessing the perception of respondents regarding specific statements or questions (Cohen, Manion \& Morrison 2000:1). Appendix 1 provides a list of all the measurement scales used in this study.

\section{Data analysis}

The analysis of the collected data was done using three statistical tools, namely Excel, SPSS version 22.0, and AMOS version 22.0. Data were coded on an Excel spreadsheet. Thereafter, the data were checked in order to identify and correct missing entries. This was followed by importing the data into the Statistical Package for Social Sciences (SPSS) format. After formatting the data into SPSS, descriptive statistics were used to analyse data pertaining to the demographic profiles of the SMEs. Subsequently, the final stages of the data analysis were conducted, which included confirmatory factor analysis (CFA) and path modelling using AMOS statistical software.

\section{Research results}

The results section is divided into three subsections, namely the profile of respondents, confirmatory factor analysis and path modelling results.

\section{Profile of participating small to medium enterprises}

The profile of SMEs that participated in the study is reported in Table 1.

Table 1 shows that the majority of participating SMEs were registered as private companies $(34.3 \% ; n=106)$, followed by sole proprietors $(24.6 \% ; n=76)$. The next most common type of ownership was partnerships at $19.7 \%(n=61)$. Nearly $39 \%$ $(n=120)$ of respondents operated in the retail environment
TABLE 1: Profile of small to medium enterprises.

\begin{tabular}{|c|c|c|c|}
\hline Variable & Category & $N$ & $\%$ \\
\hline \multirow[t]{6}{*}{ Type of business } & Cooperative & 19 & 6.1 \\
\hline & Sole proprietor & 76 & 24.6 \\
\hline & Close corporation & 47 & 15.2 \\
\hline & Private company & 106 & 34.3 \\
\hline & Partnership & 61 & 19.7 \\
\hline & Total & 309 & 100 \\
\hline \multirow[t]{9}{*}{ Nature of business } & Mining/Quarrying & 14 & 4.5 \\
\hline & Manufacturing & 44 & 14.2 \\
\hline & Retail & 120 & 38.8 \\
\hline & Construction & 25 & 8.1 \\
\hline & Transport & 34 & 11.0 \\
\hline & Community/Personal & 27 & 8.7 \\
\hline & Tourism & 17 & 5.5 \\
\hline & Finance/Tourism & 28 & 9.1 \\
\hline & Total & 309 & 100 \\
\hline \multirow[t]{5}{*}{ Number of employees } & $21-50$ & 102 & 33.0 \\
\hline & $51-100$ & 73 & 23.6 \\
\hline & $101-200$ & 65 & 21.0 \\
\hline & $201-500$ & 69 & 22.3 \\
\hline & Total & 309 & 100 \\
\hline \multirow{5}{*}{$\begin{array}{l}\text { Number of years in } \\
\text { business }\end{array}$} & Less than 2 years & 62 & 20.1 \\
\hline & $2-5$ years & 99 & 32.0 \\
\hline & $5-10$ years & 73 & 23.6 \\
\hline & More than 10 years & 75 & 24.3 \\
\hline & Total & 309 & 100 \\
\hline
\end{tabular}

whilst $14.2 \%(n=44)$ were in manufacturing and $11 \%(n=34)$ operated in the transport industry. A total of $57 \%(n=175)$ of the participating SMEs employed fewer than 100 people, whilst 21\% $(n=65)$ employed between 101 and 200 people and 22\% ( $n=69)$ employed between 201 and 500 people. This distribution shows that most jobs are created by SMEs rather than large businesses. It is also notable that a combined 52\% ( $n=161)$ of participating SMEs were fairly new businesses, having been in existence for five years or less. This also shows the kind of resilience some businesses still have despite the difficult economic times experienced in recent years.

\section{Confirmatory factor analysis}

In this study, a two-step process was followed, which entails conducting CFA prior to testing the hypotheses, as recommended by Anderson and Gerbing (1988:415).

The purpose of the CFA procedure was to examine scale accuracy in terms of internal consistency (reliability), various types of validity (construct, convergent and discriminant) and the model fit of the multiple-item construct measures used in the study (Bollen 1990:258). The results of the CFA are reported in Table 2.

As shown in Table 2, reliability was assessed through the Cronbach's alpha coefficient. The Cronbach's alpha column demonstrates that all the constructs are between 0.950 and 0.966. This suggests that all the constructs were reliable as their values were above the recommended threshold of 0.7 (Bagozzi \& Yi 1988:74; Nunnally \& Bernstein 1994:34). Furthermore, the internal reliability of each construct was also evaluated using the composite reliability (CR) index test. 
TABLE 2: Accuracy analysis statistics.

\begin{tabular}{|c|c|c|c|c|c|c|c|}
\hline \multirow{2}{*}{ Research constructs } & \multirow{2}{*}{ Factor loading } & \multicolumn{2}{|c|}{ Cronbach's test } & \multicolumn{2}{|c|}{ Descriptive statistics } & \multirow{2}{*}{$\begin{array}{c}\text { Composite } \\
\text { reliability }\end{array}$} & \multirow{2}{*}{$\begin{array}{c}\text { Average variance } \\
\text { extracted }\end{array}$} \\
\hline & & Item total & $\alpha$ value & Mean & s.d. & & \\
\hline \multicolumn{8}{|c|}{ Information sharing (IS) } \\
\hline $\mathrm{I}_{\mathrm{s}-1}$ & 0.81 & 0.828 & 0.950 & 4.261 & 0.897 & 0.95 & 0.78 \\
\hline $\mathrm{I}_{\mathrm{s}-2}$ & 0.86 & 0.865 & & & & & \\
\hline $\mathrm{I}_{s-3}$ & 0.87 & 0.842 & & & & & \\
\hline $\mathrm{I}_{\mathrm{s}-4}$ & 0.89 & 0.851 & & & & & \\
\hline$I_{S-5}$ & 0.89 & 0.865 & & & & & \\
\hline$I_{s-6}$ & 0.88 & 0.834 & & & & & \\
\hline \multicolumn{8}{|l|}{ Supplier trust (ST) } \\
\hline $\mathrm{St}_{-1}$ & 0.90 & 0.878 & 0.966 & 4.207 & 1.014 & 0.96 & 0.83 \\
\hline $\mathrm{St}_{-2}$ & 0.90 & 0.902 & & & & & \\
\hline $\mathrm{St}_{-3}$ & 0.91 & 0.892 & & & & & \\
\hline $\mathrm{St}_{-4}$ & 0.91 & 0.886 & & & & & \\
\hline $\mathrm{St}_{-5}$ & 0.90 & 0.880 & & & & & \\
\hline \multicolumn{8}{|l|}{ Supplier synergy (SSY) } \\
\hline Ssy-1 & 0.94 & 0.888 & 0.960 & 4.231 & 1.042 & 0.96 & 0.86 \\
\hline ssy-2 & 0.91 & 0.907 & & & & & \\
\hline Ssy-3 & 0.92 & 0.901 & & & & & \\
\hline Ssy-4 & 0.93 & 0.912 & & & & & \\
\hline \multicolumn{8}{|c|}{ Supplier performance (SP) } \\
\hline$S_{p-1}$ & 0.91 & 0.884 & 0.960 & 4.233 & 1.029 & 0.96 & 0.82 \\
\hline$S_{p-2}$ & 0.91 & 0.893 & & & & & \\
\hline$S_{p-3}$ & 0.90 & 0.895 & & & & & \\
\hline$S_{p-4}$ & 0.93 & 0.916 & & & & & \\
\hline$S_{p-5}$ & 0.88 & 0.852 & & & & & \\
\hline
\end{tabular}

A CR index value equal to or higher than 0.7 illustrates the adequacy of internal consistency of the construct (Hair et al. 2006:25; Nunnally 1978:4). The analysis shown in Table 2 indicates that the $\mathrm{CR}$ indexes for all the constructs were well above the requisite 0.7 , thus confirming satisfactory internal consistency of all the constructs.

Convergent validity was measured by assessing whether the individual item loading for each construct was above the recommended threshold of 0.5 (Anderson \& Gerbing 1988:417). As revealed in Table 2, the measurement instruments assessing each construct were well above the recommended 0.5: the information sharing construct (IS) had loadings ranging from 0.81 to 0.88 , supplier trust (ST) ranged from 0.9 to 0.93 , supplier synergy (SSY) ranged from 0.94 to 0.93 and supplier performance (SP) ranged from 0.91 to 0.88 . All of the loadings were beyond the required threshold of 0.5 , which indicates that the respective constructs converge well and were therefore valid. Discriminant validity was ascertained using Pearson correlation coefficient and the results indicate positive correlations with values of $r$ ranging between $0.102(p<0.01)$ and $0.860(p<0.01)$. Since these interfactor correlation values for all paired latent variables were below the recommended maximum threshold of 1.0, there was satisfactory discriminant validity in the measurement scales.

The acceptability of the model fit was established by chisquare value over degree of freedom $\left(\chi^{2} / d f\right)$, whose value should be between 1 and 3 (Schreiber et al. 2006:330), whilst the values of goodness-of-fit index (GFI), comparative fit index (CFI), incremental fit index (IFI) and Tucker-Lewis index (TLI) should be equal to or higher than 0.90 (Chinomona 2012; Hu \& Bentler 1995:76) and the root mean square error of approximation (RMSEA) value should be equal to or less than 0.08 (Browne \& Cudeck 1993:137). The results of the model fit assessment showed that $\chi^{2} / d f$ was $2.864\left(\chi^{2} / d f=670.126 / 234\right)$ and GFI, CFI, IFI, NFI and RMSEA were 0.932, 0.967, 0.967, 0.951 and 0.078 respectively. In view of the aforementioned results, it can be observed that all the indicators values meet the above stated thresholds. Therefore, the collected data were able to fit the model.

\section{Path modelling results}

The measurement of model fit of this study was done using the following indices: $\chi^{2} / d f$, GFI, CFI, IFI, NFI and RMSEA. With regard to the $\chi^{2} / d f$, the value was below the required threshold of $3\left(\chi^{2} / d f=600.210 / 234=2.565\right)$. Furthermore, GFI, CFI, IFI, NFI and RMSEA provided respective ratios of $0.91,0.95,0.94,0.911$ and 0.07 . These statistics depict that all the indicators were above the acceptable threshold of 0.9 for GFI, CFI, IFI, NFI and below that of 0.08 for RMSEA. This implies that there was acceptable model fit in the study. The results of hypotheses tests are reported in Table 3.

As shown in Table 3, the coefficient values for all hypotheses were significant at a level of $p$ less than 0.01 , with the exception of $\mathrm{H}_{5}$ which was insignificant. Thus three of the hypotheses $\left(\mathrm{H}_{1}, \mathrm{H}_{2}, \mathrm{H}_{4}\right)$ were accepted whilst one hypothesis $\left(\mathrm{H}_{3}\right)$ was rejected. 
TABLE 3: Results of structural equation model analysis.

\begin{tabular}{lcll}
\hline Path coefficients & Hypothesis & Factor loading & Decision \\
\hline Information sharing $\rightarrow$ Supplier trust & $\mathrm{H}_{1}$ & $0.345^{* * *}$ & Accepted \\
Information sharing $\rightarrow$ Supplier synergy & $\mathrm{H}_{2}$ & $0.262^{* * *}$ & Accepted \\
Supplier trust $\rightarrow$ Supplier performance & $\mathrm{H}_{3}$ & 0.124 & Not accepted \\
Supplier synergy $\rightarrow$ Supplier performance & $\mathrm{H}_{4}$ & $0.896 * *$ & Accepted
\end{tabular}

Structural model fits: $\chi^{2} / d f=2.56 ; \mathrm{GFI}=0.91 ; \mathrm{IFI}=0.94 ; \mathrm{CFI}=0.95 ; \mathrm{NFI}=0.91 ; \mathrm{RMSEA}=0.07$. $* * *$, Significance level $<0.001$.

\section{Discussion}

Hypothesis 1 postulated that there is a positive and significant relationship between information sharing and supplier trust. The results supported the stated hypothesis $\left(\mathrm{H}_{1}\right)$ which was thus accepted. This is due to the fact that a moderate and positive significant relationship was observed between information sharing and supplier trust $(r=0.345$; $p<0.01$ ). This is consistent with the observation by Kui-ran, Ji-ning and Ping (2012:43) who posited that effective and sound information shared between the buyers and their suppliers contributes significantly to improving their buyersupplier relationships. These authors further postulate that a mutual exchange of sensitive and proprietary information amongst supply chain partners correlates with the parties' willingness to engage in mutual trusting relationships. In their investigation on the impact of resource dependence, trust and relationship commitment amongst supply chain partners, Lv, Ye and Qiang (2010:7) endorse that a supply chain characterised by trust between supply chain members has a positive and significant influence on their abilities and capabilities to share key and strategic information and data. Therefore, the sharing of information between SMEs and their suppliers has an influence on supplier trust and is thus a significant antecedent factor of supplier trust.

Hypothesis 2 stated that there is a positive and significant relationship between information sharing and supplier synergy. The results of the study also supported the hypothesis $(r=0.262 ; p<0.01)$. This result is supported by a study conducted by $\mathrm{Wu}$, Chuang and Hsu (2014:122) with respect to the significance of the stated relationships. As suggested by Prajogo and Olhager (2012:514), information shared between the buying firm and suppliers is a significant enabler of collaborative synergistic behaviour in a buyersupplier supply chain relationship. Moreover, Horvath (2001:205) concedes that the key to adequate and sound synergy depends on the willingness to share relevant and reliable information by supply chain partners. In view of these results, it could be stated that information sharing is an effective driver of the suppliers' abilities to perform and operate in a synergistic manner.

As shown in Table 3, hypothesis 3, which postulated a positive relationship between supplier trust and supplier performance, was not supported by the results of the study and the relationship was found not to be significant. This result presents a different view from Dirks and Ferrin (2001:450), who described trust as a key component to organisation's performance achievement. Zhang et al. (2003:550) view trust as an essential facilitator that enables the formation of tight and long-lasting buyer-supplier relationships. Furthermore, Corsten and Kumar (2005:80) posit that high levels of trust usually result in significant performance enhancement in terms of their abilities and drive to integrate their core business operations. In their study on performance implications of power-trust relationships, Jain et al. (2014:318) established that trust is a prerequisite factor contributing to organisations' performance improvement in the retail industry. The results of the present study do not conform to the general results of previous established studies pertaining to the positive influence of the identified relation. As such, this study is amongst the few that have found supplier trust not to be a significant driver of supplier performance in the context of SMEs.

As reported in Table 3, there is a positive and significant correlation between supplier synergy and supplier performance $(r=0.896 ; p<0.01)$. These results further validate that supplier synergy has a significant influence on supplier performance in the SME sector. This result resonates with Cao and Zhang (2011:175), who determined that a supplier synergistic collaborative approach has a major and positive bearing on performance appraisals in buyer-supplier relationships. Duffy and Fearne (2004:57) and Sheu et al. (2006:24) further endorse the vital role that synergistic driven relationships have in enabling them to achieve the required level of productivity and competitiveness. Moreover, the supplier's willingness to engage in strategic synergistic partnerships has been described as effective in increasing their overall performance in terms of innovative capabilities and strategies (Parker, Zsidisin \& Ragatz 2008:71). This therefore authenticates that supplier synergy is a critical and instrumental antecedent factor enabling SMEs' suppliers to perform at the best of their capabilities.

\section{Limitations and suggestions for future research}

The present study yielded significant insights with regard to achieving the purpose of this study. However, the study is limited in scope since it was geographically restricted to businesses in southern Gauteng. An expansion of the scope of the study from SMEs to large organisations may prove vital in future studies. Future studies on the same topic may also be conducted in other geographic contexts, which could provide a basis for comparisons. Since this study used a quantitative approach, greater accuracy and other insights may be obtained if future studies make use of the mixed method, which combines both qualitative and quantitative methods. Moreover, as shown in the results, one of the four hypotheses was not supported. Future studies could add more variables or replace some of the variables used in this study for greater validity and reliability.

\section{Conclusion and managerial implications}

The aim of this study was to determine the influence of information sharing, supplier trust and supplier synergy 
on supplier performance amongst SMEs. In order to empirically investigate these suggested relationships, data were collected from a sample of 309 owners and managers of SMEs drawn from the southern Gauteng province of South Africa. Three out of the four hypotheses formulated in order to achieve the aim of the study were empirically supported and accepted. It can be concluded then that the sharing of information between SMEs and their suppliers has the effect of improving the synergistic cooperation as well as shared trust existing between these partnerships. Synergies between SMEs and their suppliers in turn have the effect of improving the performance of these suppliers. However, the existence of mutual trust between SMEs and their suppliers does not necessarily stimulate improvements in supplier performance.

The present study has managerial implications. Managers in the SME sector should strive to strengthen supplier trust and synergy existing by improving the quality and amount of information shared with suppliers. Information sharing may be increased by ensuring that the information shared with suppliers meets the expectations and requirements of both parties in terms of usefulness. This may allow for a better and more adequate utilisation in their daily operations. SMEs can also improve their supplier selection procedures and criteria in order to ensure that selected suppliers match for the profile of their enterprises. This may facilitate avoiding any unforeseen situations in which suppliers are not able to supply their partners with valuable data.

Since supplier synergy has a positive influence on supplier performance, there is a need to generate initiatives aimed at enhancing supplier synergy. SMEs should engage in mutual and joint forecast activities with their suppliers in order to develop and strengthen collaboration. This will enable these partners to reciprocate in sharing key strategies and policies as well as in providing plans aimed at coping and meeting customer demands. Furthermore, such collaborations are likely to empower the supply chain by strengthening their joint alliance as well as the integration processes, which will likely improve performance (Liu \& Kumar 2003:532). Given that the impact of supplier synergy on supplier performance is stronger than that of supplier trust, the study recommends that efforts made by SMEs to cultivate supplier synergies should be higher than those directed towards nurturing supplier trust.

\section{Acknowledgements Competing interests}

The authors declare that they have no financial or personal relationships that may have inappropriately influenced them in writing this article.

\section{Authors' contributions}

D.P. (University of Johannesburg) wrote and organised the manuscript, V.W.L-O. (Vaal University of Technology) collected data and some literature, C.M. (Vaal University of Technology) contributed in the literature review and research methodolody sections.

\section{References}

Abor, J. \& Quartey, P., 2010, 'Issues in SME development in Ghana and South Africa', International Research Journal of Finance \& Economics 39, 218-228.

Adams, J.H., Khoja, F.M. \& Kauffman, R., 2012, 'An empirical study of buyer-supplier relationships within small business organizations', Journal of Small Business Management 50(1), 20-40. http://dx.doi.org/10.1111/j.1540-627X.2011.00342.x

Ahmad, N.H., Halim, H.A. \& Zainal, S.R.M., 2010, 'Is entrepreneurial competency the silver bullet for SME success in a developing nation?', International Journal of Business Management 4(2), 67-75. http://dx.doi.org/10.3923/ibm. 2010.67.75

Aksoy, A. \& Ozturk, N., 2011, 'Supplier selection and performance evaluation in just-in-time production environments', Expert Systems with Applications 38 6351-6359. http://dx.doi.org/10.1016/j.eswa.2010.11.104

Alpkan, L., Yilmaz, C. \& Kaya, N., 2007, 'Owner-managers and business planning in the small firm', International Small Business Journal 25(2), 152-172. http://dx.doi. org/10.1177/0266242607074518

Anderson, J.C. \& Gerbing. D.W., 1988, 'Structural equation modeling in practice: A review and recommended two-step approach', Psychological Bulletin 103(3), 411-423. http://dx.doi.org/10.1037/0033-2909

Bagozzi, R.P. \& Yi, Y., 1988, 'On the evaluation of structural equation models', Journal of Academy of Marketing Science 16(1), 74-94. http://dx.doi.org/10.1007/BF02723327

Barratt, M., 2004, 'Understanding the meaning of collaboration in the supply chain', Supply Chain Management: An International Journal 9(1), 30-42. http://dx.doi. org/10.1108/13598540410517566

Bollen, K.A., 1990, 'Overall fit in covariance structure models: Two types of sample size effects', Psychological Bulletin 107(2), 256-259. http://dx.doi.org/10.1037/0033 2909.107.2.256

Bonte, W., 2008, 'Inter-firm trust in buyer-supplier relations: Are knowledge spillovers and geographical proximity relevant?', Journal of Economic Behavior and Organisation 67, 855-870. http://dx.doi.org/10.1016/j.jebo.2006.12.004

Browne, M.W. \& Cudeck, R., 1993, Alternative ways of assessing model fit, 2nd edn., Sage, Thousand Oaks, CA.

Cannon, J.P. \& Homburg, C., 2001, 'Buyer-supplier relationships and customer firm costs', Journal of Marketing 65(1), 29-43. http://dx.doi.org/10.1509/ jmkg.65.1.29.18136

Cant, M.C. \& Wild, J.A., 2013, 'Establishing the challenges affecting South African SMEs', International Business \& Economics Research Journal 12(6), 707-716.

Cao, M. \& Zhang, Q., 2011, 'Supply chain collaboration: Impact on collaborative advantage and firm performance', Journal of Operations Management 29, 163-180. http://dx.doi.org/10.1016/j.jom.2010.12.008

Cavusgil, S.T., Deligonul, S. \& Zhang, C., 2004, 'Curbing foreign distributor opportunism An examination of trust, contracts, and the legal environment in international channel relationships', Journal of International Marketing 12(2), 7-27. http:// dx.doi.org/10.1509/jimk.12.2.7.32902

Cheng, J.H., 2011, 'Inter-organizational relationships and information sharing in supply chains', International Journal of Information Management 31, 374-384. http://dx.doi.org/10.1016/j.ijinfomgt.2010.09.004

Cheng, T.C.E. \& Wu, Y.N., 2005, 'The impact of information sharing in a two-level supply chain with multiple retailers', Journal of the Operational Research Society 56, 1159-1165. http://dx.doi.org/10.1057/palgrave.jors.2601934

Cheung, S.O., Wong, W.K., Yiu, T.W. \& Pang, H.Y., 2011, 'Developing a trust inventory for construction contracting', International Journal of Project Management 29, 184-196. http://dx.doi.org/10.1016/j.ijproman.2010.02.007

Chinomona, R., 2012, 'The impact of organizational support on work spirituality, organizational citizenship behaviour and job performance: The case of Zimbabwe's small and medium enterprises (SMEs) sector', African Journal of Business Management 6(36), 10003-10014. http://dx.doi.org/10.5897/ AJBM11.2286

Chinomona, R. \& Pooe, R.I.D., 2013, 'The influence of logistics integration on information sharing and business performance: The case of small and medium enterprises in South Africa', Journal of Transport and Supply Chain Management 7(1), Art. \#92, 9 pages. http://dx.doi.org/10.4102/jtscm.v7i1.92

Cohen, L., Manion, L. \& Morrison, K., 2000, Research methods in education, 5th edn., Routledge Falmer, London.

Corsten, D. \& Kumar, N., 2005, 'Do suppliers benefit from collaborative relationships with large retailers? An empirical investigation of efficient consumer response adoption', Journal of Marketing 69(3), 80-94. http://dx.doi.org/10.1509/jmkg. 69.3.80.66360

Dirks, K.T. \& Ferrin, D.L., 2001, 'The role of trust in organizational settings', Organisation Science 12(4), 450-467. http://dx.doi.org/10.1287/orsc.12.4.450.10640

Doney, P.M. \& Cannon, J.P., 1997, 'An examination of the nature of trust in buyer-seller relationships', Journal of Marketing 61(2), 35-51. http://dx.doi. org/10.2307/1251829

Duffy, R. \& Fearne, A., 2004, 'The impact of supply chain partnerships on supplier performance', International Journal of Logistics Management 15(1), 57-72. http://dx.doi.org/10.1108/09574090410700239 
Gao, T., Sirgy, M.J. \& Bird, M.M., 2005, 'Reducing buyer decision-making uncertainty in organizational purchasing: Can supplier trust, commitment, and dependence help?', Journal of Business Research 58(4), 397-405. http://dx.doi.org/10.1016/ help?', Journal of Business

Gosh, A. \& Fedorowicz, J., 2008, 'The role of trust in supply chain governance', Business Process Management Journal 14(4), 453-470. http://dx.doi.org/10.1108/ 14637150810888019

Gray, B., 1985, 'Conditions facilitating interorganizational collaboration', Journal of Human Relations 38(10), 911-936. http://dx.doi.org/10.1177/ 001872678503801001

Gray, B., 1989, Collaborating: Finding common ground for multiparty problems, Jossey-Bass, San Francisco, CA

Hair, J.F., Anderson, R.E, Tatham, R.L. \& Black, W.C., 2006, Multivariate data analysis, 6th edn., Prentice-Hall, London.

Handfield, R.B. \& Bechtel, C., 2002, 'The role of trust and relationship structure in improving supply chain responsiveness', Journal of Industrial Marketing Management 31, 367-382. http://dx.doi.org/10.1016/S0019-8501(01)00169-9

Hartono, E., Li, X., Na, K.S. \& Simpson, J.T., 2010, 'The role of the quality of shared information in interorganizational systems use', International Journal of Information Management 30, 399-407. http://dx.doi.org/10.1016/j.ijinfomgt.2010.02.007

Ho, L.I., Feng, S.Y., Lee, Y.C. \& Yen, T.M., 2012, 'Using modified IPA to evaluate supplier's performance: Multiple regression analysis and DEMATEL approach', Expert Systems with Applications 39, 7102-7109. http://dx.doi.org/10.1016/j. Expert Systems with
eswa.2012.01.034

Hoegl, M. \& Wagner, S.M., 2005, 'Buyer-supplier collaboration in product development projects', Journal of Management 31(4), 530-548. http://dx.doi. org/10.1177/0149206304272291

Horvath, L., 2001, 'Collaboration: The key to value creation in supply chain management', International Journal of Supply Chain Management 6(5), 205-207. http://dx.doi.org/10.1108/EUM0000000006039

Hsu, C.C., Kannan, V.R., Tan, K.C. \& Leong, G.K., 2008, 'Information sharing, buyer-supplier relationships, and firm performance: A multi-region analysis', International Journal of Physical Distribution \& Logistics Management 38(4), 296-310. http://dx.doi.org/10.1108/09600030810875391

Hu, L.T. \& Bentler, P.M., 1995, Evaluating model fit in structural equation modeling Concepts, issues, and applications, Sage, Thousand Oaks, CA

Huang, M.H., Yen, G.F. \& Liu, T.C., 2014, 'Re-examining supply chain integration and the supplier's performance relationships under uncertainty', International Journal of Supply Chain Management 19(1), 64-78. http://dx.doi.org/10.1108/SCM-04 2013-0114

Jain, M., Khalil, S., Johnston, W.J. \& Cheng, J.M.S., 2014, 'The performance implications of power-trust relationship: The moderating role of commitment in the supplier-
retailer relationship', Industrial Marketing Management 43, 312-321. http:// dx.doi.org/10.1016/j.indmarman.2013.09.001

Jraisat, L., Gotsi, M. \& Bourlakis, M., 2013, 'Drivers of information sharing and export performance in the Jordanian agri-food export supply chain: A qualitative study', International Marketing Review 30(4), 323-356. http://dx.doi.org/10.1108/IMR 03-2012-0056

Kelepouris, T. Miliotis, P. \& Pramatari, K., 2008, 'The impact of replenishment parameters and information sharing on the bullwhip effect: A computational study', Computers and Operations Research 35, 3657-3670. http://dx.doi. study', Computers and Operat
org/10.1016/j.cor.2007.04.004

Kembro, J. \& Naslund, D., 2014, 'Information sharing in supply chains, myth or reality? A critical analysis of empirical literature', International Journal of Physical Distribution \& Logistics Management 44(3), 179-200. http://dx.doi.org/10.1108/ Distribution \& Logistics
IJPDLM-09-2012-0287

Ketkar, S., Kock, N., Parente, R. \& Verville, J., 2012, 'The impact of individualism on buyer-supplier relationship norms, trust and market performance: An analysis of data from Brazil and the U.S.A.', International Business Review 21, 782-793. $\mathrm{http}: / / \mathrm{dx}$.doi.org/10.1016/j.ibusrev.2011.09.003

Kim, K., 2000, 'On interfirm power, channel climate, and solidarity in industrial distributor-supplier dyads', Journal of the Academy of Marketing Science 28(3), 388-405. http://dx.doi.org/10.1177/0092070300283007

Krause D.R., Handfield R.B. \& Tyler B.B., 2007, 'The relationships between supplie development, commitment, social capital accumulation and performance improvement', Journal of Operations Management 25(2), 528-545. http://dx.doi. org/10.1016/j.jom.2006.05.007

Kui-ran, S., Ji-ning, W. \& Ping, W., 2012, 'Impact of information sharing and buyer dependence among supply chain members on trust and strategic flexibility', International Journal of Management Science and Information Technology 6, 43-65.

Kwon, I.G. \& Suh, T., 2005, 'Trust, commitment and relationships in supply chain management: A path analysis', Supply Chain Management: An International Journal 10(1), 26-33. http://dx.doi.org/10.1108/1359854051057835

Leung, Y.K., Choy, K.L. \& Kwong, C.K., 2010, 'A real-time hybrid information-sharing and decision support system for the mould industry', Journal of High Technology Management Research 21, 64-77. http://dx.doi.org/10.1016/j.hitech.2010.02.008

Li, S., Ragu-Nathan, B., Ragu-Nathan, T.S. \& Subba Rao, S., 2006, 'The impact of supply chain management practices on competitive advantage and organizational performance', Omega: International Journal of Management Sciences 34, 107 124. http://dx.doi.org/10.1016/j.omega.2004.08.002

Liu, E. \& Kumar, A., 2003, 'Leveraging information sharing to increase supply chain configurability', paper presented at the Proceedings of the 24th International Conference on Information Systems, Paper 44, viewed 27 August 2014, from http://aisel.aisnet.org/icis2003/44/
Lv, H., Ye, F. \& Qiang, R., 2010, 'Impact of resource dependence, trust and relationship commitment among supply chain partners on information system alignment', Industrial Engineering and Management 15(6), 7-15.

Mahadea, D. \& Pillay, M.K., 2008, 'Environmental conditions for SMME development in a South African province', South African Journal of Economic and Management Sciences 11(4), 431-448.

Malhotra, N.K. \& Birks, D.F., 2007, Marketing research, 3rd edn., Pearson Education Limited, Essex.

Mols, N.P., Hansen, J.R. \& Villadsen, A.R., 2012, 'Plural governance: The effect of internal production on supplier performance', Journal of Industrial Marketing Management 41, 874-885. http://dx.doi.org/10.1016/j.indmarman.2011.09.022

Nicolaou, A.I., Ibrahim, M. \& Van Heck, E., 2013, 'Information quality, trust, and risk perceptions in electronic data exchanges', Decision Support Systems 54, 986-996. $\mathrm{http}: / / d x$.doi.org/10.1016/j.dss.2012.10.024

Nielsen, B.B., 2007, 'Determining international strategic alliance performance: A multidimensional approach', International Journal of Business Review 16(3), 337-361. http://dx.doi.org/10.1016/j.ibusrev.2007.02.004

Nielsen, B.B. \& Nielsen, S., 2009, 'Learning and innovation in international strategic alliances: An empirical test of the role of trust and tacitness', Journal of Management Studies 46(6), 1031-1056. http://dx.doi.org/10.1111/j.1467-6486.2009.00840.x

Nunnally, J.C., 1978, Psychometric theory, 2nd edn., McGraw-Hill, New York, NY.

Nunnally, J.C. \& Bernstein, I., 1994, Psychometric theory, 3rd edn., McGraw-Hill, New York, NY.

Nyaga, G.N., Whipple, J.M. \& Lynch, D.F., 2010, 'Examining supply chain relationships: Do buyer and supplier perspectives on collaborative relationships differ?' Journal of Operations Management 28(2), 101-114. http://dx.doi.org/10.1016/j. jom.2009.07.005

Osarenkhoe, A., 2010, 'A study of inter-firm dynamics between competition and cooperation: A coopetition strategy', Journal of Database Marketing and Custome Strategy Management 17, 201-221. http://dx.doi.org/10.1057/dbm.2010.23

Panayides, P.M. \& Lun, Y.H.V., 2009, 'The impact of trust on innovativeness and supply chain performance', International Journal of Production Economics 122(1), 35-46. $\mathrm{http}: / / \mathrm{dx}$.doi.org/10.1016/j.ijpe.2008.12.025

Parker, D.B., Zsidisin, G.A. \& Ragatz, G.L., 2008, 'Timing and extent of supplier integration in new product development: A contingency approach', Journal of Supply Chain Management 44(1), 71-83. http://dx.doi.org/10.1111/j.1745-493X.2008.00046.x

Parker, K., 2007, 'Current trends in supply chain management', Manufacturing Business Technology (September), 2.

Perrini, F., 2006, 'SMEs and CSR theory: Evidence and implications from an Italian perspective', Journal of Business Ethics 67, 305-316. http://dx.doi.org/10.1007/ s10551-006-9186-2

Piderit, R., Flowerday, S. \& Von Solms, R., 2011, 'Enabling information sharing by establishing trust in supply chain: A case study in the South African automotive industry', South African Journal of Information Management 13(1), 473-478. http://dx.doi.org/10.4102/sajim.v13i1.473

Pooe, R.I.D. \& Mathu, K., 2011, 'The South African coal mining industry: A need for a more efficient and collaborative supply chain', Journal of Transport and Supply Chain Management 5(1) 316-336.

Prahinski, C. \& Benton, W.C., 2004, 'Supplier evaluations: Communication strategies to improve supplier performance', Journal of Operations Management 22, 39-62. http://dx.doi.org/10.1016/j.jom.2003.12.005

Prajogo, D., Chowdhury, M., Yeung, A.C.L. \& Cheng, T.C.E., 2012, 'The relationship between supplier management and firm's operational performance: A multidimensional perspective', International Journal of Production Economics 136, 123-130. http://dx.doi.org/10.1016/j.ijpe.2011.09.022

Prajogo, D. \& Olhager, J., 2012, 'Supply chain integration and performance: The effects of long-term relationships, information technology and sharing, and logistics integration', International Journal of Production Economics 135, 514-522. http:// integration', International Journal of Prod
dx.doi.org/10.1016/j.ijpe.2011.09.001

Ranganathan, C., Teo, T.S.H. \& Dhaliwal, J., 2011, 'Web-enabled supply chain management: Key antecedents and performance impacts', International Journal of Information Management 31, 533-545. http://dx.doi.org/10.1016/j. ijinfomgt.2011.02.004

Sanchez-Rodriguez, C., Hemsworth, D. \& Martinez-Lorente, A.R., 2005, 'The effect of supplier development initiatives on purchasing performance: A structural model', Supply Chain Management: An International Journal 10(4), 289-301. http:// dx.doi.org/10.1108/13598540510612767

Sandada, M., Pooe, R.I.D. \& Dhurup, M., 2014, 'Strategic planning and its relationship with business performance among small and medium enterprises in South Africa", International Business \& Economics Research Journal 13(3), 659-670.

Scannell, T.V., Vickery, S.K. \& Droge, C.L., 2000, 'Upstream supply chain management and competitive performance in the automotive supply industry', Journal of Business Logistics 21(1), 23-48.

Schreiber, J.B., Stage, F.K., King, J., Nora, A. \& Barlow, E.A., 2006, 'Reporting structural equation modeling and confirmatory factor analysis results: A review', Journal of Educational Research 99(6), 323-337. http://dx.doi.org/10.3200/ JOER.99.6.323-338

Selin, S.W. \& Chavez, D., 1995, 'Developing a collaborative model for environmental planning and management', Journal of Environmental Management 19(2), 189-195. http://dx.doi.org/10.1007/BF02471990

Sheu, C., Yen, H.R. \& Chae, D., 2006, 'Determinants of supplier-retailer collaboration: Evidence from an international study', International Journal of Operations and Production Management 26(1), 24-49. http://dx.doi.org/ 10.1108/01443570610637003 
Shou, Z., Yang, L., Zhang, O. \& Su, C., 2012, 'Market munificence and inter-firm information sharing: The moderating effect of specific assets', Journal of Business Research 66(10), 2130-2138. http://dx.doi.org/10.1016/j.jbusres.2013.02.039

Sidik, I.G., 2012, 'Conceptual framework of factors affecting SME development: Mediating factors on the relationship of entrepreneur traits and SME performance' Procedia Economics \& Finance 4, 373-383. http://dx.doi.org/10.1016/S22125671(12)00351-6

Talluri, S. \& Sarkis, J., 2002, 'A model for performance monitoring of suppliers', International Journal of Production Research 40(16), 4257-4269. http://dx.doi. org/10.1080/00207540210152894

Wasti, S.N. \& Wasti, S.A., 2008, 'Trust in buyer-supplier relations: The case of the Turkish automotive industry', Journal of International Business Studies 39, 118-131.

Wong, C.W.Y., Lai, K.H. \& Ngai, E.W.T., 2009, 'The role of supplier operational adaptation on the performance of IT-enabled transport logistics under environmental uncertainty', International Journal of Production Economics 122(1), 47-55. http:// dx.doi.org/10.1016/j.ijpe.2008.12.023

Wu, I.L., Chuang, C.H. \& Hsu, C.H., 2014, 'Information sharing and collaborative behaviours in enabling supply chain performance: A social exchange perspective' International Journal of Production Economics 148, 122-132. http://dx.doi. org/10.1016/j.ijpe.2013.09.016
Wu, Z. Choi, T.Y. \& Rungtusanatham, M.J., 2010, 'Supplier-supplier relationships in buyersupplier-supplier triads: Implications for supplier performance', Journal of Operations Management 28, 115-123. http://dx.doi.org/10.1016/j.jom.2009.09.002

Yeung, J.H.Y., Selen, W., Zhang, M. \& Huo, B., 2009, 'The effects of trust and coercive power on supplier integration', International Journal of Production Economics 120, 66-78. http://dx.doi.org/10.1016/j.ijpe.2008.07.014

Yeung, K., Lee, P.K.C., Yeung, A.C.L. \& Cheng, T.C.E., 2013, 'Supplier partnership and cost performance: The moderating roles of specific investments and environmental uncertainty', International Journal of Production Economics 144, 546-559. http:// dx.doi.org/10.1016/j.ijpe.2013.04.008

Yilmaz, C., Sezen, B. \& Kabadayi, E.T., 2004, 'Supplier fairness as a mediating factor in the supplier performance-reseller satisfaction relationship', Journal of Business Research 57, 854-863. http://dx.doi.org/10.1016/S0148-2963(02)00485-X

Zhang, C., Cavusgil, S.T. \& Roath, A.S., 2003, 'Manufacturer governance of foreign distributor relationships: Do relational norms enhance competitiveness in the export market?', Journal of International Business Studies 34(6), 550-556. http:// dx.doi.org/10.1057/palgrave.jibs.8400051

Zhang, J. \& Chen, J., 2013, 'Coordination of information sharing in a supply chain', International Journal of Production Economics 143(1), 178-187. http://dx.doi. org/10.1016/j.ijpe.2013.01.005 


\section{APPENDIX 1: Measurement scale items \\ Information sharing}

\begin{tabular}{|c|c|c|c|c|c|c|c|c|}
\hline C1 & We inform our suppliers in advance of changing needs. & Strongly disagree & 1 & 2 & 3 & 4 & 5 & Strongly agree \\
\hline $\mathrm{C} 2$ & Our suppliers share proprietary information with us. & Strongly disagree & 1 & 2 & 3 & 4 & 5 & Strongly agree \\
\hline C3 & Our suppliers keep us fully informed about issues that affect our business. & Strongly disagree & 1 & 2 & 3 & 4 & 5 & Strongly agree \\
\hline C4 & Our suppliers share the knowledge of core business processes with us. & Strongly disagree & 1 & 2 & 3 & 4 & 5 & Strongly agree \\
\hline C5 & We and our suppliers exchange information that is useful in business planning. & Strongly disagree & 1 & 2 & 3 & 4 & 5 & Strongly agree \\
\hline C6 & $\begin{array}{l}\text { We and our suppliers keep each other informed about developments that may } \\
\text { affect the other partners. }\end{array}$ & Strongly disagree & 1 & 2 & 3 & 4 & 5 & Strongly agree \\
\hline
\end{tabular}

\section{Supplier trust}

\begin{tabular}{|c|c|c|c|c|c|c|c|c|}
\hline E1 & $\begin{array}{l}\text { The relationship between our business and its major suppliers is characterised } \\
\text { by high levels of trust. }\end{array}$ & Strongly disagree & 1 & 2 & 3 & 4 & 5 & Strongly agree \\
\hline E2 & We generally trust our major suppliers to stay within the terms of the contract. & Strongly disagree & 1 & 2 & 3 & 4 & 5 & Strongly agree \\
\hline E3 & $\begin{array}{l}\text { Our major suppliers do not try to alter the facts in order to get concessions } \\
\text { from us. }\end{array}$ & Strongly disagree & 1 & 2 & 3 & 4 & 5 & Strongly agree \\
\hline E4 & Our major suppliers are good at keeping their promises. & Strongly disagree & 1 & 2 & 3 & 4 & 5 & Strongly agree \\
\hline E5 & We trust that our suppliers will deliver goods and services on time. & Strongly disagree & 1 & 2 & 3 & 4 & 5 & Strongly agree \\
\hline E6 & We trust that our suppliers will deliver high quality most of the time. & Strongly disagree & 1 & 2 & 3 & 4 & 5 & Strongly agree \\
\hline
\end{tabular}

\section{Supplier synergy}

\begin{tabular}{|c|c|c|c|c|c|c|c|c|}
\hline F1 & We are happy with the relationships that we have with our suppliers. & Strongly disagree & 1 & 2 & 3 & 4 & 5 & Strongly agree \\
\hline F2 & Part of our profits are realised from procurement cost savings. & Strongly disagree & 1 & 2 & 3 & 4 & 5 & Strongly agree \\
\hline F3 & Our suppliers depend on our business for achieving their business goals. & Strongly disagree & 1 & 2 & 3 & 4 & 5 & Strongly agree \\
\hline F4 & Our suppliers have some level of bargaining power. & Strongly disagree & 1 & 2 & 3 & 4 & 5 & Strongly agree \\
\hline
\end{tabular}

\section{Supplier performance}

\begin{tabular}{|c|c|c|c|c|c|c|c|c|}
\hline G1 & Our suppliers provide us with goods and services of good quality. & Strongly disagree & 1 & 2 & 3 & 4 & 5 & Strongly agree \\
\hline G2 & Our suppliers deliver products on time. & Strongly disagree & 1 & 2 & 3 & 4 & 5 & Strongly agree \\
\hline G3 & Our suppliers provide the right quantity of goods. & Strongly disagree & 1 & 2 & 3 & 4 & 5 & Strongly agree \\
\hline G4 & Our suppliers are conveniently located. & Strongly disagree & 1 & 2 & 3 & 4 & 5 & Strongly agree \\
\hline G5 & The procurement costs of our suppliers' products are highly competitive. & Strongly disagree & 1 & 2 & 3 & 4 & 5 & Strongly agree \\
\hline
\end{tabular}

